\title{
Role of training \& development on employee retention and organizational commitment in the banking sector of Pakistan
}

\author{
Muhammad Aleem ${ }^{\text {a }}$, Zulfiqar Ahmad Bowra ${ }^{\text {b }}$ \\ a Hailey College of Commerce, University of the Punjab, Lahore, Pakistan \\ Email; aleem12884@yahoo.com \\ ${ }^{\mathrm{b}}$ Hailey College of Commerce, University of the Punjab, Lahore, Pakistan \\ Email; zulfiqar.hcc@pu.edu.pk
}

\begin{tabular}{l} 
ARTICLE DETAILS \\
\hline History: \\
Accepted 27 August 2020 \\
Available Online 30 September \\
2020
\end{tabular}

Keywords:

Retention, Training, Human

Capital, Commitment, Banks

JEL Classification:

J31, J24, E58, E59

DOI: $10.47067 /$ reads.v6i3.252

\begin{abstract}
The value of human capital can easily be increased with the help of training \& development because investment made on personnel is very helpful for the success of the firms in the current competitive era to increase retention and commitment level of staff. The major objective of this study is to examine the role of training \& development on employee retention and organizational commitment in the banking sector of Pakistan. The population of the study consists of major eight banks of Pakistan including Islamic, foreign, public and private banks. The sequential exploratory design was followed where qualitative and quantitative data collection methods were used. Purposive sampling was used for the interview while for questionnaire multistage sampling was used. The finding of the study clearly indicates that training \& developments have significant affiliation and effect on employee retention and commitment. The training \& development play a very vital role in employee career growth, compensation, skills enhancement and capacity building to provide quality services to the clients to achieve organizational objectives.
\end{abstract}

(C) 2020 The authors. Published by SPCRD Global Publishing. This is an open access article under the Creative Commons Attribution-

NonCommercial 4.0

\section{Introduction}

Employee Retention is a mixture of different procedures, arrangement and policies which can retain the staff for a longer period (Nasir et al., 2019). It is helpful to improve competitive advantages and increased the intellectual capabilities of the organization by reducing unnecessary expenditures on staffing and training. The retention of employees is the greatest challenge for the $21^{\text {st }}$ century which should be addressed properly (Iqbal et al., 2017). In the developing countries, lower retention level is common due to many pull and push factors (Najib et al., 2019), thus there is a need to focus on retention practices in these countries. The issue regarding retention of staff is also faced by Pakistan being a developing country (Ghulam et al., 2019). There is an acute shortage of skilled staff in every 


\section{Review of Economics and Development Studies, Vol. 6 (3) 2020, 639-650}

field, thus this country is unable to achieve economic prosperity and sustainable development goals. The retention of staff is helpful for the organization in many ways i.e. loss of the relationship, reputation, monetary and talent (Aman-Ullah, Aziz, et al. 2020).

In the current era, every organization is pugnacious stiff to design such type of appropriate strategy that is helpful to reduce turnover and increase retention rate. The organizations have released that employee skills are the most important element for competitive advantages. Many retention strategies are available which includes compensation, training, promotion etc. Organizations have realized that competitive advantage could be attained with the help of a skilled workforce. Some organizations focus on specialized training instead of general training so that the employees are unfit for competitors, while some other organizations cogitate that employee's skills and training are an investment that will provide a return in the shape of employee retention and commitment (Sani 2012). Employee retention and commitment are based on the proper planning of training by considering their needs and requirement (Anvari et al., 2010). Kyndt et al (2009) stated that training is a very important factor that is helpful to change the thought process of turnover.

Training \& development has been greeted as a fundamental organizational strategy to influence human capital growth and employee retention (Chen, 2014). Human capital includes imperceptible resource time, efforts and ability that staff invests for the success of the organization. Gratton and Ghoshal (2003) stated that human capital includes emotional, social and intellectual capital. There are 4 M's in the organization which are very important for the organization i.e. material, machines, money and men. Nothing can be done efficiently and effectively without the involvement of manpower. Organizations invest in training to increase organizational and individual performance. Training whether mentally, intellectually, socially, physically are very important to facilitate the process to increase productivity as well as the development of staff in any organization.

Training \& development is one of the major areas of HRM. Training and Development activities are a systematic effort by organizations to maintain and improve the quality of their workforce. Training \& development is a continuous process and take place in the organization on or off the job and increase the productivity and quality services to the clients. Training is one of the major elements to improve and maintain the current job performance and development focus to increase employee skills for future or higher job (Duah \& Danso, 2017).

Training of staff is an organized development of skills, attitudes and knowledge to perform the specific task efficiently and effectively (Oluoch, 2013). It is a generally accepted principle for all types of organizations that training of staff is very important to prepare them to meet the current era challenges and to achieve the desired objectives of the organization with the help of relevant skills, experience and knowledge. Training \& development is very important and crucial factors to retain the employees in the organization for the long term. (Oluoch, 2013; Gupta, Bostrom, \& Huber, 2010; Aguinis, \& Kraiger, 2009). The training reduces the supervision cost and it also improves the quality, initiative and drives the movement of staff to complete the tasks to achieve organizational goals and competitiveness. For the success of the organization re-training and training of all staff should be compulsory in the form of seminars, conferences and workshops (Duah \& Danso, 2017).

The successful retention strategy is that which is helpful to the realm the knowledge within the organization. When an employee is leaving the organization, the knowledge gap is created. Moreover, the organization also faces the issue regarding the reduction in productivity of the organization (Chen, 2014). Thus it is in the best interest of the organization to analyze the situation why employees are 


\section{Review of Economics and Development Studies, Vol. 6 (3) 2020, 639-650}

leaving the organization. The benefits of the training are well documented in the literature which includes enhancing skill, productivity, decrease absenteeism accidents and wastage (Chen, 2014). Instead, to focus on empowerment there is a need to focus on training to improve employee performance. The most important benefit of training \& development is the retention of an employee in the organization for the long term particularly for those employees who are ambitious and motivated for career growth in the specific sector (Chen, 2014).

In the current dynamic environment, mostly employees are interested to learn new things to take responsibility for career growth and earning. Training plays a very important role to increase employee loyalty and commitment towards the organization because it is helpful for career growth. The current study is based on this fact that the banking sector growth is dependent on the growth and development of their HR. For sustainable development of the organization, there is a dire need to satisfy the customers and employee's needs and demands. Training \& development of staff taking the organizations toward its destination to compete in the current era. There is a dire need for the organization to train its employees to enhance productivity and efficiency. Thus the current study explores the intricacies of training \& development of the staff working under fervent competition in the banking sector for staff retention to compete in the modern era. The major objective of the study is to explore the training practices and their role in employee retention and organizational commitment in the banking sector of Pakistan.

\section{Literature Review}

Some years ago, many organizations were not interested to invest in the training due to involvement of high cost but due to recent competitive development, the alternative job opportunities are available in the market and that is the reason the organization focusing the need of training in the current era (Kraimer et al. 2011). If the organization desired that the organizational income should not reduce then there is to need to reduce the turnover of staff. (Omoikhudu, 2017). The retention of staff is better than the hiring of staff in the organization because it is the most appropriate strategy to encourage all employees to work in the organization for the long term ( Ratna and Chawla, 2012).

The retention of an employee is a great challenge for the employees in the current era and many organizations lose their best employees due to poor management (Kavittha et, al., 2011). It is a major loss for any organization when trained employees leave the organization and it also affects the loyalty and commitment of other staff. The employees who leave the organization also take away the secret and knowledge belonging to the current organization for the benefit of another organization (Jaseel 2019).

\section{Training \& Development}

Training \& development is one of the most important retention strategies and it is very useful for companies working in the modern era (Govaerts et al., 2011). The new employees feel comfortable in the new environment due to training and not frustrated at the start of a job which is helpful to perform his duties efficiently and effectively. The organization can increase retention and productivity level by using ample training programs in the current global competitive world (Ngethe, 2013). This can be achieved only by spending huge money to enhance employee experiences, information, skills, competence which are harmonious with the swift and compound mutable environment.

The continuous training programs in the firms give a message to the staff that the organization is giving weightage to them for increase their skills which ultimately enhances commitment and retention level toward the current organization (Dockel, 2003). It is an investment for development 


\section{Review of Economics and Development Studies, Vol. 6 (3) 2020, 639-650}

and enhancement of employee's skills which have a significant impact on employee retention (El Sagheir NM 2014; Mishra S 2013; Nirmala N 2015; Thite \& Russel, 2010; Sinha R, 2012). The suitable training practices increase the retention of staff because it strengthens them. (Kyndt, et al., 2009; Visser, 2001).

The employee feels motivated and cherished because of additional skills and the researcher stated there is a strong association between employee retention and training \& development(Neog and Barua 2015; Gul, Akbar et al. 2012; Perera, 2019, Wijesiri et al., 2019). The following hypothesis is developed to find out the role of training \& development.

H1: Training \& development has a significant role on employee retention in the banking sector of Pakistan.

Training \& development is one of the major factors effecting organizational commitment and there is a strong association between these variables (Ab, Rahman, et al., 2012). The training practices of the organization create a good image and repute of the firms to fascinate the preeminent applicants to join it (McElroy, 2001). When the organization is investing in the employee in the shape of training, it gives a message to the staff that the organization is committed to enhancing employee skills for competition. In reciprocal of this investment, the staff is also committed to the firms for the long term (Arlond, 2005; Bernsen et al., 2009).

Ghazanfar, Chuanmin et al. (2012) conducted a study on the banking sector and concluded that there is a strong association between commitment and training. When the organizations make spending on the organization it will attract the employees emotionally, which increases their level of commitment (Jeet and Sayeed 2014). Many researchers argued that there is a strong and significant effect of training on organizational commitment (Eunice, 2014; Piyasena, 2016; Hassan and Mahmood, 2016; Coffie et al., 2018). The following hypothesis is developed to find out the role of training \& development.

H2: Training \& development has a significant role on organizational commitment in the banking sector of Pakistan.

\section{Theoretical framework}

Based on literature the following theoretical framework is developed.
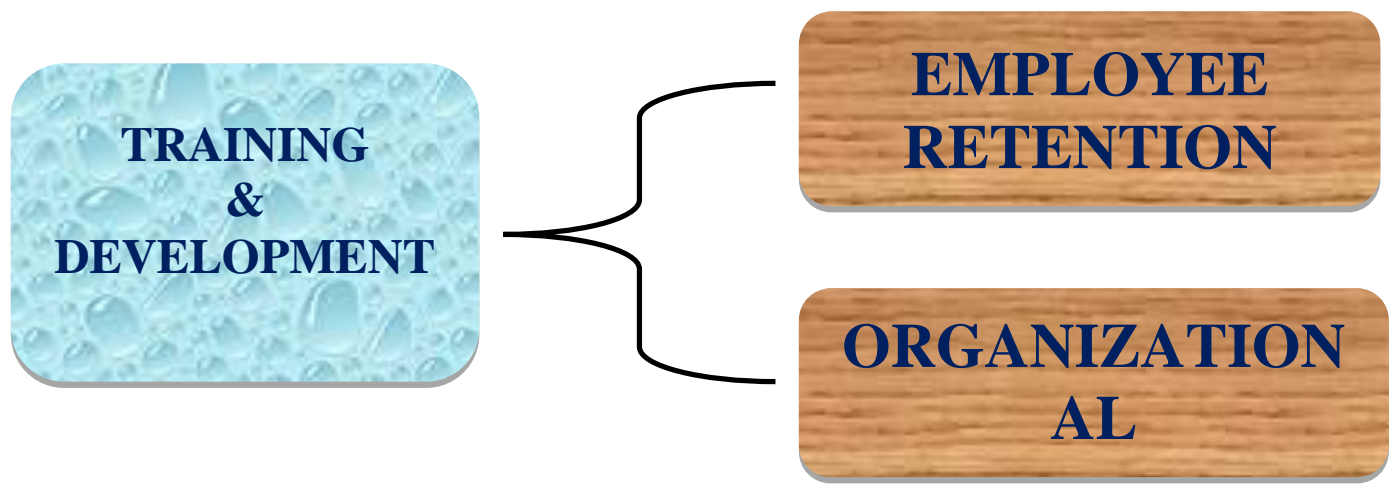

\section{Methodology}

The mixed-method approach was used for data collection to validate the research findings through quantitative and qualitative methods. The population of the current study is Human resource 


\section{Review of Economics and Development Studies, Vol. 6 (3) 2020, 639-650}

managers and managerial level employees working in the banking sector of Pakistan. The data was collected from the major eight banks of Pakistan including foreign, Islamic, private and public sector. 24 interviews were carried out form the HR managers through purposive sampling techniques by selecting three managers from each category of the bank. The quantitative data was collected with the help of adapted questionnaires by using multistage sampling techniques. The sample size was 480 which were calculated based on the model provided by Krejcie \& Morgan (1970). 6o participants were selected from each bank based on stratified random sampling which was based on gender, level of management and job status for a true representation of the population. The Cronbach alpha value of the questionnaire was more than 0.70 which indicated that the instrument was reliable for data collection. The response rate was $79 \%$ which was considered very good for analysis.

The qualitative analysis was made by Nvivo software by developing themes and nodes. The quantitative analysis was made by SPSS using descriptive, correlation, reliabilities and regression equation.

\section{Findings of the study}

The qualitative and quantitative findings of the study are discussed below briefly.

\subsection{Qualitative analysis}

The question was asked from the respondents whether the bank is making an investment in the shape of training \& development and what is its role for retention and commitment of staff in banks. The managers responded that training plays a very vital role to retain the employees long term in the banking sector because staff required as per the requirement of the market and industry to gain competitive advantages. The response from one of the manager regarding importance of training is as under.

"The training is being conducted regularly and quarterly training is being provided as per instructions of State Bank of Pakistan. In case of any new system, latest version, IT software the training is being arranged in the Lahore. After getting new skills and training, the employee feels motivated because he considers that the management has trusted him to enhance his skills to increase his performance. Due to training his commitment and loyalty also increase because they feel that the bank gives them a priority by giving them training".

The training practices are the regular feature of each bank. The response of another participant is as under.

"There is a proper training mechanism in this bank. The training is being arranged at local, regional and head office level as per the requirement of the employees. The training also plays an important role in employee retention and commitment".

The response from one of the interview participants is as under.

"The bank is spending a lot of money on employee training. The banks also ensured that in case of leaving the employee he will bear the training expenditures. The training plays a very important role to increase employee loyalty, satisfaction, motivation and commitment because training has a direct link with the monetary benefits in terms of promotion and career growth.

During the interview from the HR manager, it is perceived that fresh employees are more 


\section{Review of Economics and Development Studies, Vol. 6 (3) 2020, 639-650}

motivated and committed with the training programs as compare to experienced persons. The manager of the foreign bank stated their bank is giving due importance to the training to enhance employee commitment and retention.

"The training \& development facilities are helpful to provide guidelines, policies, product knowledge, grooming, rules \& regulation. The training session is being arranged regularly based on need assessment. The training programs are based on the performance appraisal of the employees. After completion of training the test is also being arranged whether the participant gets knowledge from the training or not and its results are shared online with the entire staff member to see the progress of the particular individual in the training. Thus employees give due attention to the training.

At the start of the year, the schedule of training is being issued in the public sector. The training is being arranged to enhance capacity building and specialized training on different issues i.e. General sale tax matters, income tax, revenue matters and any new scheme provided by the Govt. The following figure 1 indicates the factors which have a direct and indirect effect to increase the retention level of employees in the banking sector of Pakistan.

Figure 1: Role of training \& development

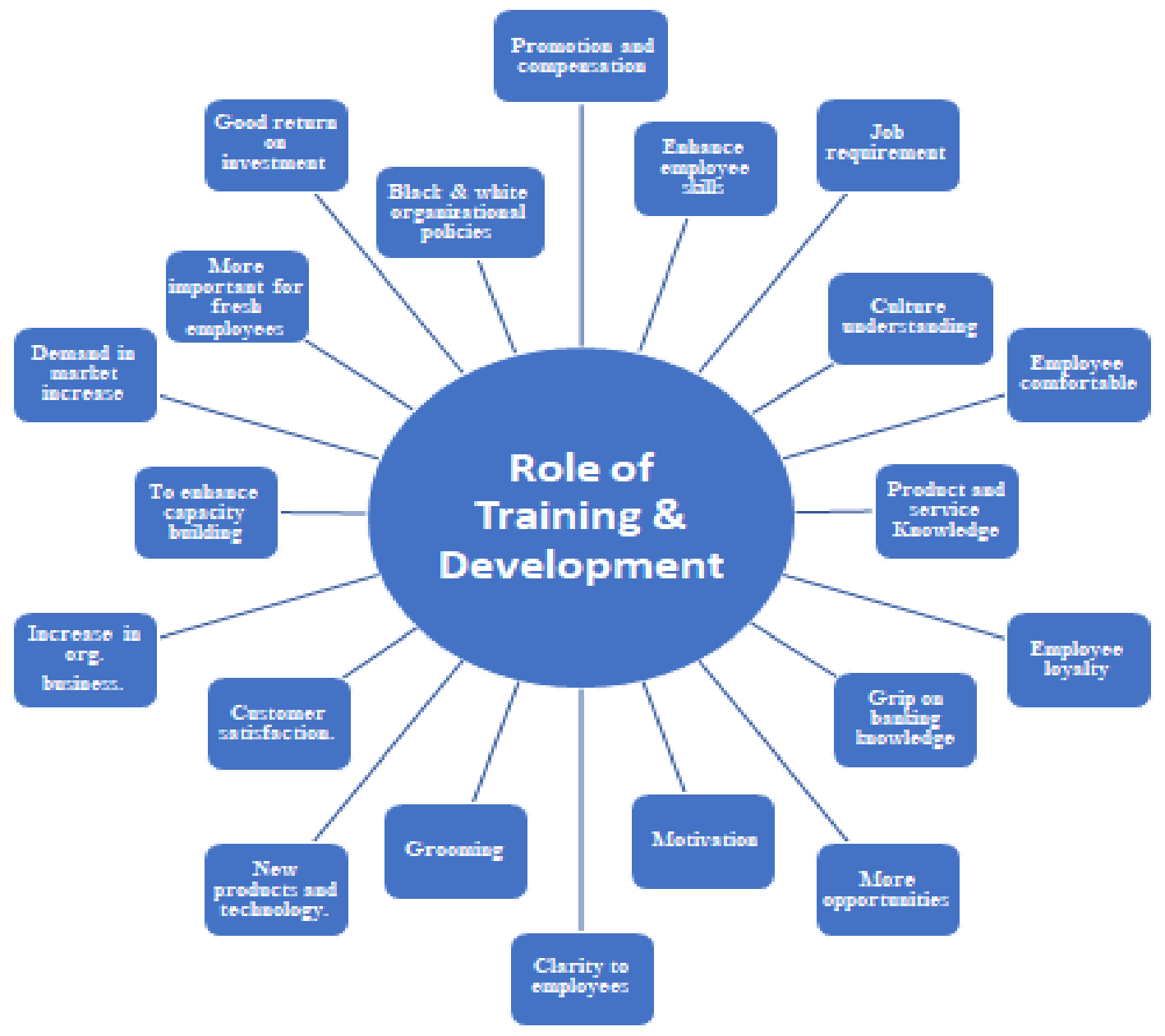

The training is not only necessary to enhance skills and knowledge but it is more important for the new workforce to provide information and rules about banking products and services. If an employee has poor knowledge about products and services then it is very difficult for him to satisfy and 
retain the customer with the bank for a long time. In view of the above discussion, it is clear that training plays a very vital role to retain the employees in the bank for a longer period.

\subsection{Descriptive statistics}

The following table provides the descriptive statistics of variables.

Table1: Descriptive Statistics

\begin{tabular}{|l|l|l|l|l|l|}
\hline & $\begin{array}{l}\text { Minimu } \\
\mathrm{m}\end{array}$ & $\begin{array}{l}\text { Maximu } \\
\mathrm{m}\end{array}$ & Mean & $\begin{array}{l}\text { Std. } \\
\text { Deviation }\end{array}$ & Median \\
\hline Training & 1.00 & 5.00 & 3.9895 & .79901 & 4.00 \\
\hline Retention & 1.00 & 5.00 & 3.5711 & .85812 & 4.00 \\
\hline Org. Commit & 1.00 & 5.00 & 3.5737 & .86707 & 4.00 \\
\hline & & & & & \\
\hline
\end{tabular}

The average mean score of training, commitment and retention is equal to 4 which mean that the respondents are satisfied with these variables. The median value also indicates the 4 scores and as per the questionnaire, it is on the agreed point of likert scale.

\subsection{Correlation}

The correlation analysis has been carried out to find the relationship between training \& development and employee retention. The range of the correlation falls between -1 to 1 from perfect negative to a positive correlation.

Table 2: Correlations between T\&D and Retention

\begin{tabular}{|l|l|c|}
\hline & \multicolumn{2}{|c|}{ Training \& } \\
\hline Retention & 1 & \multicolumn{1}{|c|}{$.163^{* *}$} \\
\hline $\begin{array}{l}\text { Training \& } \\
\text { Dev. }\end{array}$ & $.163^{* *}$ & 1 \\
\hline & & \\
\hline
\end{tabular}

The value of correlation is $0.163^{* *}$ in above table 2 indicate that there is a significant association between these two variables in the banking sector of Pakistan. There is a direct association between these variables which means that change in training will effect directly on employee retention. The results are in line with the previous finding of Neog \& Barua (2015).

\subsection{Regression Analysis}

The regression analysis is made to find out the evidence of linear effect and association between retention and training \& development. The following table provides the results of the regression equation. 
Table 3: Regression Analysis of Retention

\begin{tabular}{|c|c|c|c|}
\hline $\begin{array}{l}\text { R } \\
\text { R Square } \\
\text { Standard Error } \\
\text { F } \\
\text { Sig. }\end{array}$ & \multicolumn{3}{|c|}{$\begin{array}{l}.455^{\mathrm{a}} \\
.225 \\
.726498 \\
98.909 \\
. \text { oooa }\end{array}$} \\
\hline Independent Variable & Beta & t-value & Sig. \\
\hline (Constant) & & $15 \cdot 989$ & .000 \\
\hline Training \& development & .455 & 9.945 & .001 \\
\hline
\end{tabular}

The above regression table 3 shows that one unit change in training will change the retention level by 0.455 in the banking sector of Pakistan. R square indicates the explanatory power of the model which illuminates that $23 \%$ variation in the dependent variable is explained by the training \& development and the remaining change may be explained by other practices and policies. $\mathrm{F}$ ratio is 98.909 which indicate that the regression equation is significant statistically. The P-value is significant at less than 0.01 which clearly indicates that training \& development has a significant role to increase employee retention and we accept the alternative hypothesis. The finding of the study is also matched with the results found by Hussain \& Rehman (2013) wherein $t$ value is significant at $5 \%$ level of significance.

\subsection{Correlations analysis between Training \& development and organization commitment}

The following table displays the correlation matrix of organizational commitment and training \& development.

Table 4: Correlations between T\&D and organizational commitment

\begin{tabular}{|l|l|l|}
\hline & Org.Commit & Training \& Dev \\
\hline Org.Commit & 1 & $.123^{*}$ \\
\hline $\begin{array}{l}\text { Training \& } \\
\text { Dev. }\end{array}$ & $.123^{*}$ & 1 \\
\cline { 2 - 3 } & & \\
\hline
\end{tabular}

The above table shows the significant association between these two variables because the value of $\mathrm{r}$ is $.0123^{*}, \mathrm{P}<0.5$. The results of this study are also matched with the previous study conducted by T.Mangaleswaran \& P.T Srinivasan (2015).

\subsection{Regression Analysis}

The following table provides the results of the Regression equation to identify the role of training \& development on organizational commitment. 
Table 5: Regression Analysis of Organizational commitment

\begin{tabular}{|c|c|c|c|}
\hline $\begin{array}{l}\text { R } \\
\text { R Square } \\
\text { Standard Error } \\
\text { F } \\
\text { Sig. }\end{array}$ & \multicolumn{3}{|c|}{$\begin{array}{l}.411 \\
.206 \\
.79143 \\
76.903 \\
. \text { oooa }\end{array}$} \\
\hline Independent Variable & Beta & t-value & Sig. \\
\hline (Constant) & & 16.273 & .000 \\
\hline Training \& Dev & .411 & 18.769 & .016 \\
\hline
\end{tabular}

The results of the regression table also endorse the finding of the correlation matrix and it is concluded that training \& development has a significant role and effect on organizational commitment. The beta value is 0.411 which is significant at $5 \%$ and the results of this study are also supported by the previous study conducted by Meyer et al., 2004. The F value is also significant at $1 \%$ which is an indication of a good model fit.

\section{Discussion}

In the banking sector of Pakistan, the training \& development practices are the regular exercise to enhance employee knowledge, skills and experiences. The qualitative and quantitative results clearly indicate that training \& developments have a significant effect on employee retention and commitment and these variables have a strong association. However, there is a need of proper assessment before arranging training programs instead to repeat the training programs again and again. The finding of the study is also matched with the previous authors (Liang, 2015; Cloutier and Felusiak 2015; Ghazanfar et al., 2012). The staff feels motivated, committed and secured when they get training on the expenses of the banks which give a clear indication of their importance for the bank, which ultimately has a significant effect on their retention and commitment. The competitors are willing and attract the trained employee to get a competitive advantage to achieve organizational objectives, therefore organization focus on training to reduce turnover of staff.

\section{Implication}

Training \& development practices have a substantive effect and association on commitment and employee retention, thus there is a dire need to invest in the training to increase commitment and retention in the banking sector of Pakistan. There should be continuous and consistent training programs as per the local needs and requirements of the employees to provide efficient and quality services to the customer based on skills and expertise. The foreign banks decide on the basis of performance appraisal regarding training which should be adopted to other banks. It should also be linked with the promotion and career growth of the staff. The survey should also be conducted after the training whether it improves the employees' skills and capabilities and if there are no changes then there is a need to revise the training schedule as per proper need assessment. Training is helpful to provided quality services as per the expectation of the management and customers.

\section{Conclusions}

It is concluded from the above discussion the human capital is one of the most important 


\section{Review of Economics and Development Studies, Vol. 6 (3) 2020, 639-650}

elements for the organization's success in the current knowledge economy because it is irreplaceable resource equipped with skills, experience and knowledge skill to make valuable virtues.

Training develops a feeling of obligation in the employees and reciprocally employees make committed to the organization. When employees are obliged and committed they will stay in the organization for the long term. Due to training, the staff feels that the organization has trust and supports them which decrease employee turnover intention. The training is an investment that ultimately provides the return to the organization. The training \& development also play important role in promotion, compensation, motivation, loyalty, product knowledge, grooming, skills, job requirement, motivation and understanding the rules \& regulations of the bank.

\section{Future Direction}

In the current study we have considered only one HR practices and in future other practices i.e. job security, leadership, working environment, compensation etc. should also be considered to identify its role on retention and commitment. The demographical variables are also important in commitment and retention which have been ignored in the current study. The comparative study of different sector regarding training \& development should also be made and this factor can also be study in any other sector to generalize the finding.

\section{References}

Ab Rahman, R. (2012). "A study on turnover intention trend in commercial banks in Penang, Malaysia." Unpublished Masters Thesis: Universiti Sains Malaysia.

Aguinis H, Kraiger K. Benefits of training and development for individuals and teams, organizations, and society. Annual review of psychology. 2009; 60:451-474.

Ahmad, U. (2013). "Impact of training on employee retention." Case Business School.

Aman-Ullah, A., A. Aziz, et al. (2020). "A Systematic Review of Employee Retention: What's Next in Pakistan?" Journal of Contemporary Issues and Thought 10: 36-45.

Anvari, R. et al., 2011. Strategic training practices and turnover intention: The mediating role of organizational commitment. International journal of business and management studies, 3 (2), 293-305.

Arlond, E. (2005). Managing human resources to improve employee retention. The Health Care Manager, 24(2), 132-140.

Chen, M. (2014). The effect of training on employee retention. 2014 International Conference on Global Economy, Commerce and Service Science (GECSS-14), Atlantis Press.

Cloutier, O., Felusiak, L., Hill, C. \& Pemberton-Jones, E. J. (2015). The Importance of Developing Strategies for Employee Retention. Journal of Leadership, Accountability $\backslash \&$ Ethics, 12(2).

Coffie RB, Boateng KA and Coffie F (2018). Achieving Organizational Commitment through HRM Practices: The Ghanaian Banking Sector Experience. International Journal of Business and Management; Vol. 13, No. 5; 2018 ISSN 1833-3850 E-ISSN 1833-8119.

Dockel, A. (2003). The Effect of Retention Factors on Organisational Commitment: An Investigation of High Technology Employees. Master of Human Resource Thesis. University of Pretoria.

Duah, P., \& Danso, B.A. (2017). The impact of training and development on retention of employees in capital bank in Ghana. International Journal of Academic Research and Development, 2(5), 526532.

El Sagheir NM. An empirical study of the impact of HR practices on employee satisfaction and employee retention: The case of AASTMT. Proceedings of 3rd European Business Research Conference 4 5 September 2014, Sheraton Roma, Rome, Italy, ISBN: 978-1-922069-59-7;2014.

Eunice, A. E. (2014). "The influence of human resource management practices on organizational 


\section{Review of Economics and Development Studies, Vol. 6 (3) 2020, 639-650}

commitment: A study of manufacturing organizations in Nigeria." Indian Journal of Commerce and Management Studies 5(1): 18.

Ghulam, W.A., Ali, W., Ali, S., Khan, M.M., Khan, R.N.A., \& Farooq, M. (2019). Investigating Factors Influencing Brain Drain of Citizens of Azad Kashmir Pakistan. The Journal of Social Sciences Research, 5(3), 782-788.

Govaerts, N, Kyndt, E., Dochy, F., and Baert, H (2011),'Influence of learning and working climate on the retention of talented employees'. Journal of Workplace Learning, 23 (1): pp. 35-55

Gul, A., S. Akbar, et al. (2012). "Role of Capacity Development, Employee empowerment and Promotion on Employee Retention in the banking sector of Pakistan." International Journal of Academic Research in Business and Social Sciences 2(9): 284.

Gupta S, Bostrom RP, Huber M. End-user training methods: what we know, need to know. ACM SIGMIS Database. 2010; 41(4):9-39.

Hassan, S. and B. Mahmood (2016). "Relationship between HRM practices and organizational commitment of employees: An empirical study of textile sector in Pakistan." International Journal of Academic Research in Accounting, Finance and Management Sciences 6(1): 23-28.

Iqbal, S., Guohao, L., \& Akhtar, S. (2017). Effects of job organizational culture, benefits, salary on job satisfaction ultimately affecting employee retention. Review of Public Administration and Management, 5(3), 1-7.

Jaseel, J. (2019). Impact of training and development on employee retention of the sales team in Vodafone at United Kingdom, Dublin Business School.

Jeet, V. and U. Sayeed (2014). "A Study of Human Resource Management Practices and Organizational commitment in Self Financed Professional Institutions." International Journal 2(1).

Kavitha, S. R., Geetha, S.R. and Arunachalam, V. (2011) 'An empirical study on employee retention strategies in a biscuit manufacturing company in India'. Interdisciplinary Journal of Contemporary Research in Business, 3(4): p. 762-772.

Kraimer, M., Seibert, S. Wayne, J. Liden, C. and Bravo J. (2011) 'Antecedents and outcomes of organizational support for development: The critical role of database'. Journal of Applied Psychology, 96(3): p. 485-500.

Krejcie, R. V., \& Morgan, D. W. (1970). Determining sample size for research activities. Educ Psychol Meas.

Kyndt, E., Dochy, F., Michielsen, M., \& Moeyaert, B. (2009). Employee retention: Organisational and personal perspectives. Vocations and Learning, 2(3), 195-215.

Mishra S, Mishra D(2013). Review of literature on factors influencing attrition and retention. International Journal of Organizational Behaviour \& Management Perspectives.2013;2(3):435444 .

Najib, M., Abdullah, S., Narresh, S., \& Juni, M. H. (2019). Brain-drain phenomenon among healthcare workers. International Journal of Public Health and Clinical Sciences, 6(3), 90-103.

Nasir, F., Ashraf, M., \& Riaz, M. (2019). The Role of Gender in Employee Retention: A Study of Private Hospitals in Karachi. International Journal of Experiential Learning \& Case Studies, 4(1), 157171.

Neog, B. B., \& Barua, M. (2015). Factors Affecting Employee's Retention in Automobile Service Workshops of Assam : An Empirical Study. The SIJ Transactions on Industrial, Finance \& Business Management (IFBM), 3(1), 9-18.

Nirmala N (2015). Effectiveness of human resource management practices on faculty retention in higher education: An empirical study in Mysore City. EPRA International Journal of Economic and Business Review. 2014;2(4):54-60.

Oluoch JO (2013). Influence Of Best Human Resource Management Practices On Organizational Performance: A Case of College of Humanities And Social Sciences University Of Nairobi, Kenya 


\section{Review of Economics and Development Studies, Vol. 6 (3) 2020, 639-650}

(Doctoral dissertation, University of Nairobi).

Omoikhudu, J. (2017). The Impact of Training and Development on Employee Retention in the Retail Sector, an Examination of the Role of Coaching in a Leading Retailer in Dublin, Republic of Ireland. A Case Study of Mark and Spencer's Store Dublin, Dublin, National College of Ireland.

Perera, G. (2019). "Quantitative analysis on employee retention factors in medium and large scale IT organizations in Sri Lanka.

Piyasena, C. C. (2016). "Impact of HRM Practices on Affective, Continuance and Normative Commitment of Apparel Sector Employees in Sri Lanka." Imperial Journal of Interdisciplinary Research 2(8).

Ratna, R. and Chawla, S. (2012) 'Key factors of retention and retention strategies in telecom Sector'. Global Management Review, 6(3): p.35-46.

Sani, A. D. (2012). "Strategic human resource management and organizational performance in the Nigerian insurance industry: The impact of organizational climate." Business Intelligence Journal 5(1): 8-20.

Sinha, R. (2012). Factors Affecting Employee Retention: A Comparative Analysis of two Organizations from Heavy Engineering Industry. European Journal of Business and Management, 4(3), 145162.

Thite M, Russel B. Work organization, human resource Practices and employee retention in Indian call centers. Asia Pacific Journal of Human Resources; 2010.Available:http://www98.griffith.edu.au/dspace/bitstream/handle/10072/3561

Visser, C. (2001). Succesvol verander management door appreciative inquiry Retrieved 2011, January 1, from http://m-cc.nl/succesvolverandermanagement.pdf

Wijesiri NRASS, Paranagama GS, Sirirwardhana MMAS, Thilakarathna DLNC, Weerarathna RS, Pathirana UPGY (2019). The Impact of HR Practices on Employee Retention; A Case of BPO Sector, Sri Lanka International Journal of Human Resource Studies ISSN 2162-3058 2019, Vol. 9, No. 1. http://ijhrs.macrothink.org 